\title{
PENGARUH KUALITAS PELAYANAN, PRESEPSI HARGA DAN KEMAMPUAN BERKOMUNIKASI TERHADAP KEPUASAN KONSUMEN PADA PT. JNE BABAT LAMONGAN
}

\section{Andriyan Huda Prasetiyo}

Sekolah Tinggi Ekonomi Islam Permata Bojonegoro, Jawa Timur, Indonesia.

\author{
Deni Rustamaji \\ Sekolah Tinggi Ekonomi Islam Permata Bojonegoro, Jawa Timur, Indonesia.
}

\section{Sumarni}

Sekolah Tinggi Ekonomi Islam Permata Bojonegoro, Jawa Timur, Indonesia. sumarni.seger@gmail.com

\section{Noor Iffatin Nadhifah}

Sekolah Tinggi Ekonomi Islam Permata Bojonegoro, Jawa Timur, Indonesia.

\begin{abstract}
Seiring dengan berkembangnya industri bisnis saat ini mengakibatkan beberapa perusahaan berorientasi pada permintaan pelanggan. Seperti halnya pada industri bidang pelayanan jasa, khususnya perusahaan jasa kurir yang memiliki sejumlah pelanggan dari masyarakat umum dan pelanggan corporate dimana industri bisnis tersebut mатри memudahkan produsen dan konsumen bertransaksi, meminimalisir waktu, serta memperoleh peluang bisnis baru dari kebutuhankebutuhan pelanggan yang belum tercapai. Kualitas merupakan senjata perusahaan agar dapat memenangkan persaingan, namun hampir semua perusahaan terutama perusahaan yang bergerak dibidang jasa berupaya menghasilkan kualitas yang sama. Untuk itu kualitas bukan satu-satunya jalan ampuh yang ditempuh perusahaan untuk dapat bersaing dengan kompetitornya. Menurut American Society for Quality Control, kualitas adalah keseluruhan ciriciri dan karakteristik-karakteristik dari suatu produk atau jasa dalam hal kemampuan untuk memenuhi kebutuhan-kebutuhan yang telah ditentukan atau bersifat laten (Lupiyoadi, 2001). Pendekatan kuantitatif adalah pendekatan yang disajikan dalam bentuk angka-angka atau dengan mengunakan rumus-rumus statistik untuk mengatur variabel-variabel penelitian Sugiyono (2012:157-159). Metode analisis yang digunakan dalam penelitian ini adalah regresi linier berganda yang merupakan metode untuk mencari hubungan atau pengaruh dari variabel bebas terhadap variabel terikat. Berdasarkan temuan hasil penelitian dari tiga variabel yang meliputi variabel Pelayanan (X1) sebesar (0,291), Harga (X2) sebesar (0,286), dan Komunikasi (X3) sebesar (0,556). Diketahui bahwa variabel Pelayanan (X1), Harga (X2), dan Komunikasi (X3) memiliki pengaruh yang signifikan baik secara simultan maupun secara parsial terhadap keputusan pembelian konsumen. Variabel yang berpengaruh dominan terhadap kepuasan konsumen adalah variabel Komunikasi (X3). Hasil penelitian ini yang menunjukkan bahwa semua variabel bebas memiliki pengaruh yang signifikan terhadap keputusan pembelian
\end{abstract}

Kata Kunci Pelayanan, Harga, Komunikasi, Kepuasan 


\section{PENDAHULUAN}

Seiring dengan berkembangnya industri bisnis saat ini mengakibatkan beberapa perusahaan berorientasi pada permintaan pelanggan. Seperti halnya pada industri bidang pelayanan jasa, khususnya perusahaan jasa kurir yang memiliki sejumlah pelanggan dari masyarakat umum dan pelanggan corporate dimana industri bisnis tersebut mampu memudahkan produsen dan konsumen bertransaksi, meminimalisir waktu, serta memperoleh peluang bisnis baru dari kebutuhan-kebutuhan pelanggan yang belum tercapai.

Pola pikir konsumen yang berubah seiring perkembangan zaman menuntut praktisipraktisi bisnis untuk mengembangkan industri logistik pada pangsa pasar yang luas. Secara umum ada banyak faktor yang mempengaruhi kualitas pelayanan dalam mempertahankan loyalitas pelanggan pada bidang layanan jasa. Kepercayaan pelanggan terhadap merek juga mempengaruhi mutu pelayanan yang diberikan oleh perusahaan. Alma (2004:263) mengatakan : Service Quality sebagai alat persaingan yang ampuh untuk mempertahankan pelanggan serta membangun standar kualitas yang excellence. (Jurnal FMAS Ekonomi,Manajemen dan Bisnis Vol.1 No.1 Oktober 2007).

Persaingan dalam bisnis logistik tampak ketat dan semakin terbuka lebar untuk pemain baru yang berkancah di Indonesia. Bertumbuh pesatnya bisnis ONLINE, manufaktur dan retail memicu tumbuhnya perusahaan logistik lokal, beberapa perusahaan yang meramaikan industri logistik yaitu, PT. JNE, TIKI, FedEx, DHL, dan Pos Indonesia. Perusahaan ternama tersebut saat ini berlomba-lomba mengungguli pangsa pasar yang sebagian besar dikuasai oleh perusahaan asing, hal tersebut tidak menutup kemungkinan PT. JNE bersaing untuk menjadi tuan rumah dalam wilayah domestik. PT. JNE adalah perusahaan jasa kurir pengiriman paket dalam wilayah lokal maupun internasional, pengembangan produk dan layanan yang diberikan antara lain yaitu menyediakan jasa kurir express, logistik, money remittance (transfer uang) trucking, air\&sea cargo, escort (Jasa penjemputan bandara), hingga customer clearance (jasa kapabean).

PT. JNE sebagai perusahaan logistik lokal, telah memiliki kantor perwakilan 75 unit, kantor cabang 53 unit, serta 2.073 agen dan sub-agen di seluruh Indonesia. Pengembangan produk dan layanan inovatif PT. JNE saat ini adalah Jasa pengiriman layanan Pesanan Oleholeh Nusantara (Pesona) dan Amplop prabayar PELIKAN (Pengiriman Lintas Kawasan). PT. JNE memiliki visi menjadi perusahaan logistik utama kelas dunia, oleh karena itu untuk menjadi market leader perusahaan akan berupaya memperluas segmen pasar serta meningkatkan kualitas pelayanan yang lebih beragam. (www.swa.co.id)

Pelanggan semakin kritis dan pintar dalam menyeleksi suatu merek yang memberikan mutu pelayanan berkualitas. Kondisi ini memaksa perusahaan untuk lebih sigap dalam memberikan layanan jasa yang cepat dan efisien, dan tentunya perkembangan teknologi yang semakin melaju menantang perusahaan untuk menganalisis permintaan dan kebutuhan pelanggan di masa mendatang. Akan tetapi dalam kenyataannya tidaklah mudah untuk mempertahankan pelanggan dalam wujud memberikan pelayanan yang sesuai dengan harapan mereka. Hal ini diulas oleh Ueno (2010) dalam konseptualisasi dari Service Quality yaitu adanya kesenjangan antara harapan pelanggan pada pelayanan dan persepsi pelanggan oleh kinerja pelayanannya.(Journal of Services Marketing, Vol.24, No.1, pp.74-86).

Kompetisi dalam dunia bisnis pada era globalisasi semakin tajam,pelanggan merupakan kunci utama dalam memenangkan persaingan diantara praktisi bisnis lainnya. Service Quality merupakan salah satu elemen penting dalam bauran pemasaran yang mempengaruhi pelanggan selain dari permintaan, harga, nilai dan kepuasan. Service quality merupakan faktor utama yang mempengaruhi Brand trust seorang pelanggan dalam 
meningkatkan loyalitas pelanggan. Merek sebagai aset suatu perusahaan memperoleh nilai yang memiliki keunikan dan mudah berinteraksi dengan pelanggan. Dimana pelanggan merasa aman akibat interaksinya dengan sebuah merek,maka merek tersebut handal dan bertanggung jawab atas kepentingan dan keselamatan pelanggannya

Pelayanan jasa pengiriman barang yang diberikan PT. JNE semakin beragam dan inovatif, Brand trust dan Loyalitas pelanggan sangat menentukan kualitas pelayanan yang diberikan dapat sesuai dengan harapan mereka. Mempertahankan pelanggan yang loyal, serta menjaga agar tidak beralih ke jasa pengiriman barang sejenis merupakan hal yang penting untuk mengikat pelanggan-pelanggan PT. JNE. Untuk itu perusahaan perlu membangun strategi pemasaran seperti harga yang terjangkau, promosi penjualan yang efektif untuk menarik pelanggan baru, customer service yang sigap dalam melayani pelanggan, serta jaminan pada resiko kehilangan atau kerusakan pengiriman paket yang berdampak terhadap Brand Trust dan Loyalitas Pelanggan jasa PT. JNE.

\section{TINJAUAN PUSTAKA}

\subsection{Kualitas Pelayanan}

Kualitas merupakan senjata perusahaan agar dapat memenangkan persaingan, namun hampir semua perusahaan terutama perusahaan yang bergerak dibidang jasa berupaya menghasilkan kualitas yang sama. Untuk itu kualitas bukan satu-satunya jalan ampuh yang ditempuh perusahaan untuk dapat bersaing dengan kompetitornya. Menurut American Society for Quality Control, kualitas adalah keseluruhan ciri-ciri dan karakteristik-karakteristik dari suatu produk atau jasa dalam hal kemampuan untuk memenuhi kebutuhan-kebutuhan yang telah ditentukan atau bersifat laten (Lupiyoadi, 2001).

Menurut Triyana (dalam Ferdinand, 2006) service atau pelayanan merupakan bagian yang penting dari kegiatan pemasaran produk. Pihak konsumen menuntut pula bagaimana pelayanan purna jual dari produk yang dibelinya.

Parasuraman, Zeithaml, dan Berry (1996) mendefinisikan kualitas pelayanan sebagai suatu bentuk sikap, berkaitan tetapi tidak sama dengan kepuasan, sebagai hasil dari pembandingan antara harapan dengan kinerja. Service quality adalah suatu instrumen yang digunakan oleh pelanggan untuk menilai pelayanan atau jasa yang diberikan oleh perusahaan. Kotler (2006) mengatakan bahwa kualitas jasa (service quality) harus dimulai dari kebutuhan pelanggan dan berakhir pada persepsi pelanggan, persepsi pelanggan terhadap kualitas jasa merupakan penilaian menyeluruh atas keunggulan suatu pelayanan.

\subsection{Persepsi Harga}

Persepsi harga adalah bagaimana kita melihat dunia sekitar kita. Persepsi didefinisikan sebagai proses yang dilakukan individu untuk memilih, mengatur, dan menafsirkan stimuli ke dalam gambar yang berarti dan masuk akal mengenai dunia (Schiffman, G.Leon, Lazar, Leslie, 2004).

Sedangkan menurut Simamora (2002) persepsi dapat didefinisikan sebagai suatu proses dengan mana seorang menyeleksi, mengorganisasikan, menginterpretasikan stimuli dalam suatu gambaran dunia yang berarti menyeluruh. Individu terbuka terhadap berbagai pengaruh yang cenderung membelokkan persepsi mereka, yaitu sebagai berikut:

a. Penampilan fisik

Berbagai studi mengenai penampilan fisik telah menemukan bahwa model yang menarik lebih persuasif dan mempunyai pengaruh yang lebih positif terhadap sikap dan perilaku konsumen. 
b. Stereotip

Stereotip ini menimbulkan harapan mengenai bagaimana situasi, orang, atau peristiwa tertentu akan terjadi dan stereotip ini merupakan faktor penentu yang penting bagaimana stimuli tersebut dirasakan.

c. Petunjuk yang tidak relevan

Ketika diperlukan untuk membuat perkembangan yang sulit melalui persepsi, para konsumen sering kali memberi respon pada stimuli yang tidak relevan.

d. Kesan pertama

Kesan pertama cenderung pribadi, namun dalam membentuk kesan tersebut, penerima belum mengetahui stimuli mana yang relevan, penting, atau yang dapat diramalkan menjadi perilaku lainnya.

e. Terlalu cepat mengambil keputusan

Banyak orang yang terlalu cepat mengambil kesimpulan sebelum meneliti semua keterangan atau bukti yang berhubungan.

f. Efek halo

Gagasan efek halo diperluas meliputi penilaian terhadap berbagai objek atas dasar penilaian pada satu dimensi. Dengan definisi yang lebih luas, para pemasar memanfaatkan efek halo ketika mereka memperluas merek yang menghubungkan satu lini produk dengan yang lain. Produsen memperoleh pengakuan dan status yang cepat dengan mengaitkan nama yang sudah terkenal.

Persepsi juga mempunyai pengaruh yang kuat bagi konsumen. Faktor-faktor yang berpengaruh terhadap persepsi pelanggan adalah harga, citra, tahap pelayanan, dan situasi pelayanan. Persepsi perusahaan dapat dibentuk melalui strategi penetapan harga. Perusahaan dapat menetapkan harga tinggi untuk membentuk persepsi produk tersebut berkualitas. Sementara itu, harga rendah dapat membentuk persepsi pembeli tidak percaya pada penjual karena meragukan kualitas produk atau pelayanannya.

\subsection{Pengertian Pemasaran Jasa}

Perkembangan dunia bisnis pada era globalisasi menuntut kinerja yang sempurna dari setiap proses yang dijalankan perusahaan. Pemasaran tidak lagi dipandang sebagai bagian yang terpisah dari organisasi yang hanya berperan sebagai proses penjualan suatu produk. Perkembangan konsep pemasaran sendiri tidak terlepas dari fungsi-fungsi organisasi yang lain dan pada akhirnya mempunyai tujuan untuk memuaskan pelanggan. Pemasaran yang tidak efektif (ineffective marketing) dapat membahayakan bisnis karena dapat berakibat pada konsumen yang tidak puas. Pemasaran yang efektif (effective marketing) justru berakibat sebaliknya yaitu menciptakan nilai atau utilitas. Menciptakan nilai dan kepuasan pelanggan adalah inti pemikiran pemasaran modern. Tujuan kegiatan pemasaran adalah menarik pelanggan baru dengan menjanjikan nilai yang tepat dan mempertahankan pelanggan saat ini dengan memenuhi harapannya sehingga dapat menciptakan tingkat kepuasan.

Pemasaran jasa adalah perencanaan yang bergerak dari fokus pada ransaksi menjadi hubungan jangka panjang dengan pelanggan. Menurut Kotler (2005), jasa adalah setiap tindakan atau keinginan yang dapat ditawarkan oleh satu pihak kepada pihak lain, pada dasarnya jasa tidak berwujud dan tidak mengakibatkan kepemilikan apapun. Produksi jasa mungkin berkaitan dengan produk fisik atau tidak (Lupiyoadi, 2001).

Didalam jasa selalu ada aspek interaksi antara pihak konsumen dan pemberi jasa. Jasa juga bukan merupakan barang, jasa adalah suatu proses atau aktivitas, dan aktivitas-aktivitas tersebut tidak berwujud Dari definisi di atas dapat disimpulkan bahwa pemasaran jasa suatu 
tindakan yang ditawarkan pihak produsen kepada konsumen dalam arti jasa yang diberikan tidak dapat dilihat, dirasa, didengar atau diraba sebelum dibeli atau dikonsumsi. Kegiatan pemasaran jasa harus dapat mendekatkan konsumen, pelanggan, mengkaji peluang-peluang pasar, menetapkan posisi jasa segmen pasar dan pasar sasaran atas dasar kebutuhan jasa tersebut serta merumuskan bauran pemasaran (marketing mix), yang meliputi mutu dan deversifikasi jasa, harga atau tarif dari kegiatan promosi dan strategi penyampaian jasa tersebut (Hendri Sukotjo dan Sumanto Radix A., 2010)

Bauran pemasaran jasa merupakan pengembangan bauran pemasaran. Menurut Lupiyoadi (2001) bahwa elemen Marketing Mix jasa terdiri dari tujuh hal, yaitu: Product (jasa seperti apa yang ingin ditawarkan kepada konsumen), Price (bagaimana strategi penentuan harga), Place (bagaimana system penghantaran atau penyampaian yang akan diterapkan), Promotion (bagaimana promosi yang harus dilakukan), People (tipe kualitas dan kuantitas orang yang akan terlibat dalam pemberian jasa), Process (bagaimana proses dalam operasi jasa), Customer Service (bagaimana yang akan diberikan kepada konsumen).

\subsection{Kepuasan Konsumen}

Kepuasan konsumen didefinisikan sebagai tingkat perasaan seseorang setelah membandingkan kinerja (atau hasil) yang ia rasakan dibandingkan dengan harapannya (Kotler, 2005). Perbandingan antara harapan dan kinerja tersebut akan menghasilkan perasaan senang atau kecewa di benak konsumen. Apabila kinerja sesuai atau bahkan melebihi harapan, maka konsumen akan merasa senang atau puas. Sebaliknya apabila kinerja berada di bawah harapan, maka konsumen akan merasa kecewa atau tidak puas.

Menurut Basu Swastha (2000), pengertian kepuasan konsumen adalah: "Suatu dorongan keinginan individu yang diarahkan pada tujuan untuk memperoleh kepuasan. Dalam hal ini kita perlu mengetahui bahwa suatu keinginan itu harus diciptakan atau didorong sebelum memenuhi motif. Sumber yang mendorong terciptanya suatu keinginan dapat berbeda dari diri orang itu sendiri atau berada pada lingkungannya. Mowen and Minor (2002) mengatakan kepuasan konsumen didefinisikan sebagai keseluruhan sikap yang ditunjukkan oleh konsumen atas barang dan jasa setelah mereka memperoleh dan menggunakannya.

\section{METODE PENELITIAN \\ Pendekatan Penelitian}

Penulis di sini menggunakan Pendekatan kuantitatif (Deskrip Kuantitatif) adalah pendekatan yang disajikan dalam bentuk angka-angka atau dengan mengunakan rumus-rumus statistik untuk mengatur variabel-variabel penelitian Sugiyono (2012:157-159).

Metode analisis yang digunakan dalam penelitian ini adalah regresi linier berganda yang merupakan metode untuk mencari hubungan atau pengaruh dari variabel bebas terhadap variabel terikat.

Penelitian ini mengambil tempat di kota Lamongan. Pemilihan lokasi dilakukan secara sengaja/purposif dengan mempertimbangkan lokasi tersebut sebagai daerah pemukiman dan industri yang menjadi pusat mobilisasi penduduk perkotaan. Lokasi tersebut mempunyai tingkat penduduk yang padat, sehingga dapat mewakili perilaku konsumen untuk PT. JNE Babat Lamongan dan penduduk tersebut diasumsikan dapat mewakili preferensi beberapa budaya yang berbeda. Pasar atas Lamongan ini juga merupakan salah satu pasar besar di kota Lamongan dan letaknya yang berdekatan dengan PT. JNE Lamongan tepat di Jl. KH. Ahmad Dahlan Mantup Kec. Laamongan Jawa Timur 62217.

\section{Subyek Penelitian}




\section{Populasi}

Populasi dalam penelitian ini adalah pelanggan PT. JNE Babat Lamongan dengan karakteristik responden sebanyak 3000 orang.

\section{Sampel}

Sampel ialah bagian dari jumlah dan karakteristik yang dimiliki oleh populasi tersebut. Dam penelitian ini tidak keseluruan populasi diambil, melainkan hanya sebagian dari populasinya diketahui secara pasti jumlahnya penelitian ini adalah sebanyak 100 responden.

\section{Tehnik Sampling}

Tehnik sampling yang digunakan dalam penelitian ini yaitu purphosive sampling (sampling pertimbangan). Tehnik purphosive sampling adalah pengambilan sampel yang digunakan berdasarkan pertimbangan perorangan atau pertimbangan peneliti. (Sugiyono,2012:81). Jadi disini peneliti mengambil keputusan tehnik sampling berdasarkan kepentingan penelitian dari peneliti sendiri.

Teknik sampling tersebut, peneliti akan lebih mudah mendapatkan data untuk penelitian dan akan peneliti olah dengan sumus yang sudah tercantum dan akan mendapatkan data sesuai dengan yang diharapkan.

\subsection{Jenis Dan Sumber Data Penelitian}

1. Jenis Data

Berdasarkan jenis datanya, maka data dapat dibedakan sebagai berikut:

a. Data Primer

Data primer adalah data yang dikumpulkan dan diolah sendiri oleh organisasi yang menerbitkan atau menggunakanya. Data yang dikumpulkan, diolah dan digunakan sendiri oleh peneliti disebut data primer.

b. Data Sekunder

Data sekunder atau penunjang dalam penelitian ini, bersumber dari informasi yang terasal dari sumber kedua atau para responden sebagai nara sumber maupun dari pihak-pihak lain yang ada keterkaitannya dengan penelitian. Data yang diperoleh dalam bentuk sudah jadi, sudah dikumpulkan dan diolah pihak lain, biasanya sudah dalam bentuk publikasi.

2. Sumber Data

Berdasarkan sumber datanya, maka data dapat dibedakan sebagai berikut:

a. Data Internal

Data internal adalah data yang diperoleh langsung dari obyek yang diteliti. Dalam hal ini berarti data diperoleh langsung dari pihak Jne babat lamongan selaku obyek penelitian.

b. Data Eksternal

Data eksternal adalah data yang diperoleh dari pihak luar selain obyek penelitian. data yang diperoleh bisa melalui studi pustaka yang bertujuan mendapatkan literatur dan hal-hal lain yang relevan yang terkait dengan obyek yang diteliti.

Jenis data yang digunakan dalam penelitian ini adalah data-data primer, yaitu data yang sudah diolah eleh pihak JNE babat lamongan. Sedangkan sumber datanya yang penulis peroleh adalah data internal yakni data penelitian yang diperoleh secara langsung dari obyek penelitian yaitu pihak JNE babat lamongan. 


\section{Instrumen Penelitian}

Instrumen penelitian adalah sebagai alat untuk memperoleh data yang bertujuan untuk mengukur variabel-variabel penelitian yang telah dirumuskan sebelumnya berdasar pada masalah dan teori penelitian. Instrumen penelitian yang digunakan dalam penelitian ini adalah

a. Dokumentasi

Pengumpulan data atau informasi yang dilakukan dengan cara mempelajari dokumen-dokumen (laporan atau catatan) yang ada pada perusahaan.

b. Interview (wawancara)

Penelitian yang dilakukan dengan mengadakan wawancara secara langsung kepada responden untuk memberikan data dan penjelasan tentang masalah yang diteliti.

c. Kuesioner

Kuesioner merupakan teknik pengumpulan data dengan cara memberikan daftar pertanyaan berupa angket untuk diisi oleh karyawan. Angket ini penulis berikan merupakan angket tertutup karena penulis menyediakan jawaban sehingga mempermudah responden memberikan jawaban. Jenis skala pengukuran yang digunakan dalam kuesioner ini adalah skala likert. Sugiyono $(2012 ; 102)$ skala Likert digunakan untuk mengukur sikap, pendapat, dam persepsi seseorang atau sekelompok orang tentang fenomena sosial. Sehingga untuk mengetahui pengukuran jawaban responden pada penelitian ini yang mana menggunakan instrument penelitian berupa kuisioner, penulis menggunakan metode skala Likert (Likert's Summated Ratings).

Dalam pengukuran jawaban responden, pengisian kuesioner proses rekrutmen dan proses seleksi terhadap kinerja karyawan diukur dengan menggunakan skala likert, dengan tingkatan sebagai berikut :

a. Jawaban Sangat Setuju diberi bobot 5

b. Jawaban Setuju diberi bobot 4

c. Jawaban Ragu-ragu diberi bobot 3

d. Jawaban Tidak Setuju diberi bobot 2

e. Jawaban Sangat Tidak Setuju diberi bobot 1

\section{HASIL DAN PEMBAHASAN}

Berdasarkan temuan hasil penelitian dari tiga variabel yang meliputi variabel Pelayanan $\left(\mathrm{X}_{1}\right)$ sebesar $(0,291)$, Harga $\left(\mathrm{X}_{2}\right)$ sebesar $(0,286)$, dan Komunikasi $\left(\mathrm{X}_{3}\right)$ sebesar $(0,556)$. Diketahui bahwa variabel Pelayanan $\left(X_{1}\right)$, Harga $\left(X_{2}\right)$, dan Komunikasi $\left(X_{3}\right)$ memiliki pengaruh yang signifikan baik secara simultan maupun secara parsial terhadap keputusan pembelian konsumen. Variabel yang berpengaruh dominan terhadap kepuasan konsumen adalah variabel Komunikasi $\left(\mathrm{X}_{3}\right)$.

Hasil penelitian ini sama dengan hasil penelitian sebelumnya yang dilakukan oleh Rosa Adelina (skripsi, 2008) yaitu variabel yang paling dominan adalah variabel Komunikasi, sedangkan hasil penelitian lainnya menunjukkan bahwa semua variabel bebas memiliki pengaruh yang signifikan baik secara simultan maupun secara parsial terhadap kepuasan konsumen (Y).

Hasil penelitian ini yang menunjukkan bahwa semua variabel bebas memiliki pengaruh yang signifikan baik secara parsial maupun secara simultan terhadap keputusan pembelian.

\section{Implikasi Kebijakan}


Ketiga variabel ini diketahui bahwa ketiga variabel tersebut memiliki pengaruh yang signifikan dalam mempengaruhi kepuasan konsumen untuk membeli dan memakai jasa PT. JNE Babat Lamongan. Implikasi kebijakan dari ketiga variabel tersebut adalah:

a. Variabel Pelayanan $\left(\mathrm{X}_{1}\right)$

Kualitas Pelayanan memiliki beberapa tingkat pengertian yaitu kepribadian dan pemakai. Kepribadian merek mencerminkan kepribadian tertentu. Pemakai, yaitu merek menunjukkan jenis konsumen yang membeli atau menggunakan produk tersebut. Ada beberapa manfaat pelayanan diantaranya memberikan peluang bagi penjual dalam mengelompokan pasar ke dalam segmen-segmen. Selain itu adanya merek tertentu, konsumen dapat meningkatkan stastusnya dan prestisnya. Dilihat dari segi pemakai, konsumen PT. JNE Babat Lamongan dicitrakan sebagai PT. JNE Babat Lamongan yang bisa dinikmati oleh semua kalangan dan segmen karena PT. JNE Babat Lamongan selalu menjaga kepercayaan dengan menggunakan proses yang struktural maka dari itu aman oleh semua konsumen.

b. Variabel Harga $\left(\mathrm{X}_{2}\right)$

Harga, PT. JNE Babat Lamongan sebagai produsen jasa yang sangat terkenal serta kredibilitas yang sudah tidak diragukan lagi sehingga menjadi pertimbangan utama bagi konsumen untuk menggunakan jasanya. Untuk menjaga citra yang positif tersebut, maka sebaiknya tetap menjaga nama baiknya dan menjaga mutu dan kualitasnya.

c. Variabel Komunikasi $\left(\mathrm{X}_{3}\right)$

Komunikasi sebuah perusahaan dari segi konsumen berdampak pada perusahaan dan pesaingnya. Dari ketiga variabel yaitu Kualitas, Harga dan Komunikasi secara parsial, dapat diketahui bahwa variabel Komunikasi memiliki pengaruh yang dominan dibandingkan dengan kedua variabel lainya. Variabel Komunikasi tersebut dapat digunakan sebagai acuan dalam membentuk citra Produk yang kuat guna mempengaruhi kepuasan konsumen. Malalui citra produk yang kuat maka akan terbetuk adanya perasaan yang positif dalam benak konsumen terhadap produk yang ditawarkan perusahaan. Oleh karena itu hendaknya perusahaan melakukaan kebijakan dalam mempertahankan komunikasi. kebijakan tersebut yaitu secara terus-menerus melakukan riset mengenai selera konsumen atau riset pasar sehingga PT. JNE Babat Lamongan peka terhadap kebutuhan konsumen. Dasar riset ini nantinya memberikan landasan PT. JNE Babat Lamongan untuk lebih menciptakan kenyamanyan dan pelayanan baru yang nantinya bisa diterima dipasaran.

\section{KESIMPULAN}

Berdasarkan analisis dari hasil penelitian dapat diambil kesimpulan sebagai berikut:

1. Pelayanan $\left(X_{1}\right)$ sebesar $(0,203)$, dari image mempunyai pengaruh yang signifikan terhadap kepuasan konsumen pada PT. JNE Babat Lamongan.

2. Harga $\left(\mathrm{X}_{2}\right)$ sebesar $(3,655)$, dari image mempunyai pengaruh yang signifikan terhadap kepuasan konsumen pada PT. JNE Babat Lamongan.

3. Komunikasi $\left(\mathrm{X}_{3}\right)$ sebesar $(0,305)$ dari image mempunyai pengaruh yang signifikan terhadap kepuasan konsumen pada PT. JNE Babat Lamongan.

4. Variabel komunikasi dapat digunakan sebagai acuan dalam membentuk image yang kuat maka akan terbentuk adanya perasaan yang positif dalam benak konsumen terhadap PT. JNE Babat Lamongan. 
5. Dari hasil penelitian dapat disimpulkan bahwa variabel Komunikasi memiliki kontribusi yang dominan diantara variabel lainya terhadap kepuasan konsumen pada PT. JNE Babat Lamongan.

\section{DAFTAR PUSTAKA}

Ahmadi. Edy Anas. 2020. Analisis Pengaruh Kualitas, Fitur, Dan Desain Produk Terhadap Keputusan Pembelian Honda Genuine Parts Di Jun's Motor Surabaya. Maker: Jurnal Manajemen. Jilid 6. Terbitan 2. Halaman. 148-156

Basu Swastha dan Irawan, 2000 Manajemen Pemasaran Modern, Edisi Kedua, Cetakan Kedua, Penerbit: Liberty, Yogyakarta.

Basu Swasta, dan Hani Handoko, 2000, Manajemen Pemasaran Analisa Perilaku Konsumen, BPFE, Yogyakarta.

Fandy, Tjiptono, 2002, Strategi Pemasaran. Edisi Ketiga, Cetakan Pertama, Penerbit Andi Offset. Yogyakarta. 2005, Pemasaran Jasa. Edisi Pertama, Cetakan Pertama, Penerbit Andi Offset. Yogyakarta.

2 2007, Strategi Pemasaran. Edisi Kedua, Cetakan Pertama, Penerbit Andi Offset. Yogyakarta.

Fandy Tjiptono dan Anastasia Candra, 2005, Pemasaran Global: Internasionalisasi dan Internetisasi, Penerbit: Andi Offset, Yogyakarta.

Indriyo, Gitosudarmo, 2006, Manajemen Pemasaran, Edisi Pertama, Penerbit BPFE, Yogyakarta.

Indriantoro dan Supomo, 2006, Metodologi Penelitian Bisinis Untuk Akuntansi dan Manajemen, Edisi Pertama, Penerbit BPFE, Yogyakarta.

Madura, Jeff, 2001, Pengantar Bisnis, Edisi Pertama, Jilid II, Jakarta: Salemba Empat.

M Purba, D Simanjutak, Y Malau, W Sholihat, E Ahmadi. 2021. The Effect Of Digital Marketing And E-Commerce On Financial Performance And Business Sustaina-Bility Of Msmes During Covid-19 Pandemic In Indonesia. International Journal Of Data And Network Science. Jilid 5. Terbitan 3. Halaman 275-282

Kotler, Philip, 2000, Manajemen Pemasaran: Perencanaan, Implementasi dan Pengendalian, Prehallindo: Jakarta. ,2001, Manajemen Pemasaran: Perencanaan, Implementasi dan Pengendalian, Salemba Empat: Jakarta. , 2002, Manajemen Pemasaran, PT. Prenhallindo, Jakarta.

Kotler, Philip dan Gary Amstrong ,2004, Dasar-Dasar Pemasaran, Edisi Kesembilan, Jilid 1, Penerbit PT. Indeks Kelompok Gramedia: Jakarta.

Sofyan Assauri. 2001, Manajemen Produksi dan Operasi. Edisi Revisi. Lembaga Penerbit Fakultas Ekonomi Universitas Indonesia.

Suharsimi Arikunto, 2006, Prosedur Penelitian, Edisi Revisi Keempat. Penerbit Cipta, Jakarta.

Sugiyono, 2004, Metode Penelitian Bisnis, Cetakan Ketujuh, Penerbit Alfabeta CV, Bandung Sunarto, 2003, Prinsip-Prinsip Pemasaran, Cetakan Pertama, Penerbit AMUS, Yogyakarta.

Sutisna, 2002, Perilaku Konsumen dan Komunikasi Pemasaran, Cetakan Kedua, PT. Remaja Rosdakarya, Bandung.

Suryani, Tatik, 2008, Perilaku Konsumen Implikasi pada Strategi Pemasaran, Cetakan Pertama, Penerbit: Graha Ilmu, Yogyakarta.

Widayat, 2004, Riset Bisnis, Edisi 1, Malang: CV. Cahaya Press. 
E-ISSN : 2599-3410 | P-ISSN : 2614-3259

DOI : https://doi.org/10.36778/jesya.v5i1.614

Widayat dan Amirullah, 2002, Riset Bisnis, Edisi 1, Malang: CV. Cahaya Press.

Sumber : :http://just-thole.blogspot.com/2012/04/warung-kopi-pangkon-di-pasaragrobis.html (22/7/2015)

Sumber : http://ilmualambercak. blogspot.com/2013 /04/ sejarah-kopi-luwak.html $(22 / 7 / 2015)$ 